\title{
Research on Higher Education Reform and Innovation from the Perspective of Cultivating Virtue and Nurturing Personality
}

\begin{abstract}
Xin Weng
China Jiliang University, Hangzhou, 310018, China

*Corresponding author. Email:1127195706@qq.com

ABSTRACT

Carrying out the fundamental task of Cultivating Virtue and Nurturing Personality is an epoch proposition of higher education in the new era. This paper discusses the relationship between higher education and moral education from the perspective of Cultivating Virtue and Nurturing Personality, as well as the effective path to achieve connotative development and implement the fundamental task of Cultivating Virtue and Nurturing Personality in the new era. It is beneficial to the development of higher education in China by integrating educational resources, innovative teaching mode, etc., ccombining the academic research results on the implementation of Cultivating Virtue and Nurturing Personality.
\end{abstract}

Keywords: Cultivating Virtue and Nurturing Personality, Higher education, Connotative development, Three-wide education.

\section{INTRODUCTION}

On April 19, 2021, General Secretary Xi Jinping went to Tsinghua University for an inspection. In the upcoming 110th anniversary of the establishment of Tsinghua University, President Xi Jinping stressed that "Education is the foundation for a century. The development of the cause of the party and the country not only needs higher education, but also needs. It is more urgent than ever. "[]In the field of higher education, we should keep pace with The Times, deepen educational reform, advancing with times, make education agree with the development trend of The Times, cultivate talents for the development of socialism with Chinese characteristics, and strive to run the education fitting with the satisfactory of people.

\section{THE RELATIONSHIP BETWEEN "CULTIVATING VIRTUE AND \\ NURTURING PERSONALITY" AND HIGHER EDUCATION}

The key of the reform and innovation of higher education is accomplishment of the fundamental task of cultivating people by virtue, which is also an important proposition for higher education in the new Times. The essence of education lies in cultivating talents. The quintessence of the idea of "Cultivating Virtue and Nurturing Personality" is contained in our excellent traditional culture, which reflects the theoretical quintessence of our traditional moral and cultural education thoughts. The cultivation of talents has been a national event since ancient times, and "cultivating people" is not achieved overnight, but an eternal proposition related to national development. There are rich theoretical foundations for "Cultivating Virtue and Nurturing Personality", whether it is the soul of China's excellent traditional culture, the thoughts of Marxist classical writers on moral education, and the moral education thoughts of leaders of the past dynasties, which have laid a profound theoretical foundation for "Cultivating Virtue and Nurturing Personality" in the new era. Making the moral education as the fundamental task of education was first proposed in the report of the 18th National Congress of the CPC. The report of the 19th National Congress of the CPC puts forward "the fundamental task of cultivating people by virtue". Since entering the new era of socialism with Chinese characteristics, we should keep up with the Times, bring the new ideas for the new situation, In order to make the two centenary goals and the Chinese Dream of the great rejuvenation of the Chinese nation 
come true, promoting the all-round development of people and the all-round progress of society has become the mission destination of higher education reform and development.

\section{1."Cultivating Virtue and Nurturing Personality" is the Core Idea of Higher Education Thought}

The essence of education is to educate people. Tracing back to the practical course of the founding of higher education by the CPC, we can find that it has always been the initial mission of the Chinese Communists. During the revolutionary period, the Communist Party of China founded higher education. Based on the revolutionary situation at that time, its purpose was to cultivate a group of revolutionary advanced elements with strong national spirit and revolutionary will, who could shoulder heavy responsibilities and liberate the whole nation. When the Chinese nation was locked in a serious crisis, the CPC established a number of revolutionary base universities represented by Northern Shaanxi Public School, AntiJapanese Military and Political University and Lu Xun Art College to meet the needs of the comprehensive anti-Japanese war. After establishment of new China, in the face of the domestic situation that all wastes need to be revived, the purpose of establishing higher education by the CPC has changed to cultivate a group of "builders of the PPC" who serve the national socialist construction. During this period, through the development of higher education, lots and lots of talents can devote themselves to the rapid development of New China. Since the reform and opening up, we have deeply realized that the great advantages of human resources in international competition and the development level of higher education are related to a country's international competitiveness and comprehensive strength. Since entering the new era, the current development of higher education should follow the series of important expositions of president Xi Jinping on education, take moral education as the fundamental task, establish socialist morality, and train generations of useful talents who have all-round development in morality, intelligence, beauty and labor. Looking back at the various historical periods when the CPC founded higher education, the idea of "Cultivating Virtue and Nurturing Personality" is the core idea of China's higher education throughapplicates the period of revolution, construction and reform of China.

\section{2. "Cultivating Virtue and Nurturing Personality" is the Common Trend International Higher Education Development.}

"Cultivating Virtue and Nurturing Personality" as a special proposition of the times in China, although there is no specific research on moral education abroad, the research on what kind of ideology and morality citizens should have and what kind of talents to train has never stopped. In the 21 st century, the development of all countries in the world cannot be separated from talent competition, and Cultivating talents with both ability and political integrity and comprehensive development is a common trend in the development of international higher education. The educational idea of "Cultivating Virtue and Nurturing Personality" belongs to the community of human civilization [2].

In recent years, all countries around the world are carrying out educational reform intensively in order to cultivate high-quality talents. Morality is very important for maintaining social stability and development, which makes the cultivation of talents in different countries not only have professional quality, but also have higher moral quality. The indispensable core idea in the common trend of education development in various countries is to shape the national ideology and morality and lead the values. In addition to improving students' scientific and cultural level, German education departments pay great attention to cultivating students' ideological and moral qualities. They regard moral education as an important project to shape citizens' patriotic feelings and noble character, and actively promote moral education in the teaching process. Japan has always put moral education at the top of school education. Attaching importance to moral education has a long history in Japan. Japanese people pay ateention to the development of morality, intelligence and physique, especially the development of students' morality. Because Japanese moral education is a national moral education, Japanese moral education is very effective, and Japanese people have a strong sense of national identity.

"Cultivating Virtue and Nurturing Personality" is an educational idea, put forward from the basis of inheriting the excellent traditional culture of the Chinese nation and drawing lessons from the theoretical achievements and practical experience of domestic and foreign higher education. According to the actual situation of their own countries, all countries in the world cultivate high-quality talents committed to national development by means of moral education such as "general education" and "humanistic education".

\subsection{The Implementation of the Fundamental Task of "Cultivating Virtue and Nurturing Personality" is the key of the Reform and Innovation of Higher Education Lies in the}

"The country is not virtuous, and people are not virtuous." General Secretary Xi Jinping emphasized that the foundation of colleges is to cultivate people by virtue. Moral cultivation is the consistent theoretical essence and value orientation in the traditional culture inherited and developed since ancient times in China, 
and it is the mission and value goal of chinese higher education at present. The reform and innovation of higher education must focus on the fundamental task of cultivating people by virtue, strengthen the construction of socialist core value system, lead the broad masses of young people to cultivate and practice socialist core values, and make them become all-round development socialist builders and successors.

\section{THE HIGH-QUALITY CONNOTATIVE DEVELOPMENT OF HIGHER EDUCATION}

Realizing the connotative development of higher education is not only the major policy of the Party and the state on the higher education development, but also the basic requirement of running a university. [3]Connotation-based development is the core of higher education development policy after the party and the country enter a new era. The report of the 18 th National Congress of the CPC put forward; "Promoting the connotative development of higher education", the report of the 19th National Congress once again stated: "Realizing the connotative development of higher education". About higher education, we should adhere to the fundamental task of carrying out moral education, constantly reform and innovate teaching methods, intensify talent innovation, promote the high-quality development of higher education, and continuously train high-quality talents to enhance the national strategic ability and comprehensive strength.

\subsection{Adhere to the Initial Mission of "Cultivating Virtue and Nurturing Personality"}

Cultivating Virtue and Nurturing Personality is the core of developing socialist education, which is not only the foundation of colleges and universities, but also the essential requirement of training socialism with Chinese characteristics's qualified builders and reliable successors. At present, it is common for higher educationthat the intellectual education is more important than moral education, and the score is important than educating people. The trained people often have higher scientific and cultural level, but lack moral quality and personality charm. The reason is that traditional education only attaches more impotance to students' academic achievements under the social background of "scores only and diplomas only" in the past, and generally attaches less importance to the scientific and cultural education of tree people, while ignoring the establishment of people's ideological and moral qualities. "Talent, the capital of Germany is also; Virtue is also handsome." Talent cultivation must be a process of unifying education and talent cultivation, and education is the foundation. young people in the new era should be determined to learn and cultivate their morality to make Chinense Dream come true.

\subsection{Attach Importance to the Shaping of Values}

With the opening of China's door wider and wider, the youth in the new Times with active thinking and diversified interests can access a wider world stage through the Internet. However, due to the short of sufficient social experience and clear discrimination ability, they are vulnerable to the impact of Western social thoughts such as historical nihilism and neoliberalism. Cultivating socialist core values is a powerful way to defeat the challenges of various social thoughts [4]. Under the background of this era, it is extremely urgent to carry out the fundamental task of cultivating people by virtue. The presdent $\mathrm{Xi}$ is highly valued to the guidance of higher education to young students' values in the process of realizing moral education, and repeatedly emphasizes the extreme importance of ideals and beliefs and the extreme importance of shaping correct world view, view of life and values. If a person does not have correct values and moral orientation, he will fall into spiritual emptiness and confusion. If a country and a nation lose the guidance of correct values and ideals and beliefs, it will bring the nation to a standstill. Therefore, when push ahead with higher education reform and innovation, we should root socialist core values in people's hearts, and enhance Four-Sphere Confidence.

\subsection{Cultivate High-quality Campus Culture}

In the connotative development of higher education, we should fully strengthen the construction of higher education and teaching culture and cultivate highquality campus culture. Cultural edification is a subtle process, and it is also very significanceforimplicit education. The quality of higher education depends not only on the effect of classroom teaching, but also on whether a good campus culture has been shaped. Excellent campus culture is silent, but its influence is lasting and far-reaching, which often accompanies students' life. The construction of campus culture in chinese colleges is still immature, with shallow cultural background and quick success in education and teaching. Many colleges and universities are still stuck in the stubborn chronic disease of "only scores, only studies, only diplomas, only papers, only hats". To realize the connotative development of higher education, we must strengthen the construction of education and teaching culture, pay attention to creating an academic atmosphere that respects humanity, respects academics, is friendly and friendly, builds a teacher-student relationship that understands each other and grows together, and builds a learning community between the teachers and students which set the goal of all-round 
development. We should create a good learning environment, mold high-quality campus culture, and lay a cultural foundation for personnel training for the higher education developmen.

\section{THE EFFECTIVE WAY TO IMPLEMENT MORAL EDUCATION IN HIGHER EDUCATION}

\subsection{Coordinate and Promote the Work of "Three-wide education"}

In December, 2016, the president $\mathrm{Xi}$ Jinping emphasized that we should persist in taking the cultivation of moral integrity as the central link, carry out ideological and political work throughout the whole process of education and teaching, realize the whole process and all-round education, and strive to create a new situation in China's higher education. The whole process of educating people in colleges based on moral education requires that all stages of moral education should be connected with each other, and moral education should run through all stages of college students' growth and success, so as to achieve full coverage and no blank.[5]To perfect the system and mechanism of "Three-wide education", the idea of "Cultivating Virtue and Nurturing Personality" should run through the whole process of education and teaching and permeate every corner of campus culture. All departments of the whole school should have the consciousness of actively educating people, and all teachers should establish the idea of cultivating people by virtue, and constantly enhance the cooperative consciousness and ability of all units of the whole school and all educators by virtue. To educate the whole staff is to establish a multi-pronged effort of educating the whole school teachers, administrative departments, academic departments and family members. Adhering to the overall leadership of the Party Committee of the school on education, strengthening the construction of teachers' ethics and education ability, mobilizing the enthusiasm of family members for moral education should be committed to implement the task of building morality and educating people. Educating people in the whole process requires strengthening the orderly connection of moral education in different stages in colleges. The moral education in colleges must form a closed loop with the ideological and moral education in primary and secondary schools, make full use of the connection point of view to look at the moral education tasks at each stage, and formulate a training plan for each phase, which realize the whole process coverage of moral education. To educate people in all directions, it is necessary to enhance the organic combination of school education, social education and family education, meanwhile establish a cooperative education mechanism with the combination of school, society and family. With the rise of new science and technology, Internet learning is more and more accepted by the majority of young people, and massive open online courses and live classroom have created new teaching modes. While firmly building classroom education as the main position of the first class, the Internet platform to carry out education and teaching work should be full used.

\subsection{Strengthen the Construction of Teachers' Morality and Ethics}

In the report of the 19th National Congress of the Communist Party of China, General Secretary Xi Jinping pointed out: "Strengthen the construction of teachers' ethics, cultivate high-quality teachers, and advocate the whole society to respect teachers and attach importance to teaching"[6]. Higher education reform should adhere to the idea of educators first. Good teachers' ethics is an important foundation to help students grow up and become talented. Teachers can be respected only by learning to be tall and healthy, and students can learn how to behave themselves from their words and deeds. We should actively guide university teachers to stand firm and correct political positions, support the leadership of the Communist Party, practice the socialist core values, and lead by example. Colleges and universities should build a team of teachers with high academic integrity, call on teachers to learn valuable learning experience, selfless dedication and noble personality charm from experienced old teachers, and strive to make the whole school form a cultural atmosphere of respecting teachers, valuing teaching and being good at teaching.

\subsection{Deepen the Construction of "Curriculum Ideological and Political Education"}

Take curriculum ideological and political education as the basic work to implement the fundamental task of Curriculum Ideological and Political Education [7]. At the National Education Conference, General Secretary $\mathrm{Xi}$ Jinping made an important exposition on higher education in the new era, emphasizing the need to "deepen the reform of the education system and improve the implementation mechanism of moral education", so as to make the direction of curriculum ideological and political construction clearer and the goal firmer. To deepen the ideological and political construction of curriculum, we must take the basic viewpoints and methods of Marxism as the standpoint, take the school curriculum as the carrier of educating people, and carry out ideological and political education throughout the whole process of education and teaching activities. The previous course teaching in colleges and universities paid more attention to the explanation and teaching of knowledge, and the ideological and political requirements of courses broke the shackles of teaching knowledge in a single course, so that all courses and ideological and political education went in the same 
direction, thus forming a synergistic effect. Curriculum ideological and political education should first establish a correct political position and value guidance, strengthen students' ideals and beliefs, improve students' sense of national and social identity, cultivate patriotism and enhance their mission. Secondly, there is a difference between educating people and directly explaining knowledge-based classes. Ideological and political courses require teachers to quote the current international and domestic situation and policies or current affairs hotspots as an entry point in class teaching, and guide students to actively care about state affairs. At the same time, we can also use case teaching method to quote relevant cases that incorporate patriotic feelings, social responsibilities and professional ethics, which will subtly influence students to establish a correct world outlook, outlook on life and values. In the end, theoretical education should be put into practice, and ideological and political courses should pay attention to strengthening practical links, and fully apply the theoretical knowledge learned in class to life practice, so as to truly apply what you have learned.

\section{CONCLUSIONS}

By studying the reform and innovation of higher education in China from the perspective of "Cultivating Virtue and Nurturing Personality", higher education should actively undertake the important task of moral education. Facing the new situation, in order to achieve high-quality connotative development of higher education, it is necessary to adhere to the concept of" Cultivating Virtue and Nurturing Personality", actively promote the work of "Comprehensive education", and deepen the construction of "curriculum ideological and political education". It is necessary to focus on realizing the Chinese dream of the great rejuvenation of the Chinese nation, persist in cultivating people by virtue in all aspects of school work, and cultivate generations of qualified people who are struggling for socialist construction.

\section{REFERENCES}

[1] Xi Jinping: Adhere to the goal of building a worldclass university with Chinese characteristics and contribute to serving the country's prosperity and national rejuvenation and people's happiness. [N] People's Daily, April 20, 2021

[2] Jin Nuo Cultivating Virtue and Nurturing Personality: the fundamental task of higher education and the mission of the times. China's higher education $[\mathrm{J}] 2017.11 .16$

[3] Bie Dunrong. On the connotative development of higher education. China Higher Education Research [J] 2018.
[4] Liu Cong. General Secretary Xi Jinping's important exposition on the ideological and political work in colleges and universities. [D]2019

[5] Gou Jianqiang. Research on the Path of "Threeround Education" in Colleges and Universities Based on Lide Shuren. [D] 2020

[6] Xi Jinping: Winning the victory in building a welloff society in an all-round way and winning the great victory of socialism with Chinese characteristics in the new era - Report at the 19th National Congress of the Communist Party of China [N]. People's Daily, October 19, 2017.

[7] Han Xianzhou. Promote the practical innovation of Lideshu people with curriculum ideological and political education [J] China's higher education. 2019 